\title{
Hurricane Katrina and the Inner Harbor Navigation Canal Lake Borgne Surge Barrier
}

\author{
Dale MILLER, PE, SE${ }^{1}$, Angela DESOTO-DUNCAN, $\mathrm{PE}^{2}$, Beth HERTZLER ${ }^{3}$
}

\author{
${ }^{1}$ Regional Vice President/Tetra Tech, dale.miller@tetratech.com \\ 2.Director of Civil Works/Tetra Tech, angela.desotoduncan@tetratech.com \\ 3. Contributing Editor/Tetra Tech, beth.hertzler@tetratech.com
}

\begin{abstract}
Louisiana's Inner Harbor Navigation Canal (IHNC) Lake Borgne Surge Barrier is the central feature of the world's largest Hurricane and Storm Damage Risk Reduction System (HSDRSS), As well as the largest design-build civil works project in the history of the US Army Corps of Engineers (USACE). After four years of intense effort and innovation, the 10,000-foot-long surge barrier is complete. Not only has the project been a vital component in the reconstruction and revitalization of New Orleans after the devastating events of Hurricane Katrina, it has provided innovative methods and empirical knowledge gained during the design and construction of the surge barrier that inform the industry and others across the globe (Fig. 1).
\end{abstract}

Key-words: Lake Borgne, flood protection, flood wall, hurricane, storm

\section{L'ouragan Katrina et la barrière de protection du canal de navigation du port intérieur du Lac Borgne}

\begin{abstract}
RÉSUMÉ. - La barrière de protection du Lac Borgne et du canal de navigation du port intérieur de Louisiane (IHNC) est l'ouvrage majeur du plus grand système au monde pour la réduction des risques et des dommages liés aux orages et aux ouragans (HSCRSS). C'est également le plus grand projet d'édifice civil que l'on doit au Corps des Ingénieurs de l'Armée de terre des Etats Unis (USACE). Après quatre ans d'efforts intenses et d'innovations, le système de protection de près de 3.5 kilomètres de long est achevé. Le projet n'est pas seulement une composante vitale de la reconstruction et de la revitalisation de la Nouvelle Orléans suite aux destructions dues à l'ouragan Katrina : il a permis de développer des méthodes innovantes, fruits de l'expérience acquise lors de la conception de l'ouvrage, pour le bénéfice de l'industrie et d'autres opérateurs qui œuvrent sur de semblables sujets à travers le monde.
\end{abstract}

Mots-clés : Lac Borgne, protection contre les crues, digue, ouragan, orage

\section{NEW ORLEANS AND HURRICANE KATRINA}

New Orleans, as unique in geography as it is in culture, rests between the east bank of the Mississippi river and the south shore of Lake Pontchartrain approximately 105 miles north of the Gulf of Mexico (Fig 2). The city sits an average of 6 feet below sea level, making it entirely dependent on levee systems in the wake of a storm surge (Fig. 3). However, in late August of 2005, category five Hurricane Katrina descended on the Gulf with an intensity far superior than the previously established system could withstand (Fig. 4).

The storm surge's forces breached 50 floodwalls and levees as well as collapsing a 4,000-foot-long floodwall section of the Inner Harbor Navigation Canal (IHNC), a central waterway connecting the Mississippi with Lake Borgne and the Gulf of Mexico (Fig. 5). As a result, over 90,000 square miles of the city was devastated and many historic neighborhoods were submerged under 15 feet of water. Katrina left behind $\$ 81$ billion USD in damage, over 1,800 fatalities and displaced thousands of residents from their homes and livelihoods.

\section{THE NEED FOR CHANGE}

Before Katrina, the hurricane protection system was a system in name only, and consisted of a collection of projects in various stages of completion. Constructed over a period of forty years, the pre-Katrina system was inconsistent, utilizing various design criteria and datums. In order to eliminate the inconsistencies of the past and implement a true system, the United States Congress authorized and fully appropriated the funds for USACE to implement the \$14.4 Billion USD HSDRSS. The new solution had to be strategically designed to reduce the risk from hurricane storm surges, which along with along with the flooding of the Mississippi River, rainfall, and coastal erosion is one of the four major flood risks to the New Orleans area. Separate but overlapping or related interagency systems or programs were needed to address each element. The strategic improvements goals of the HSDRRS on the east bank of the Mississippi River were to raise and strengthen the existing levees and floodwalls to the current design standards, stormproof key pump stations so they can function throughout a tropical event, and block the five present storm surge avenues from a 100 -year storm surge (Fig. 6) 


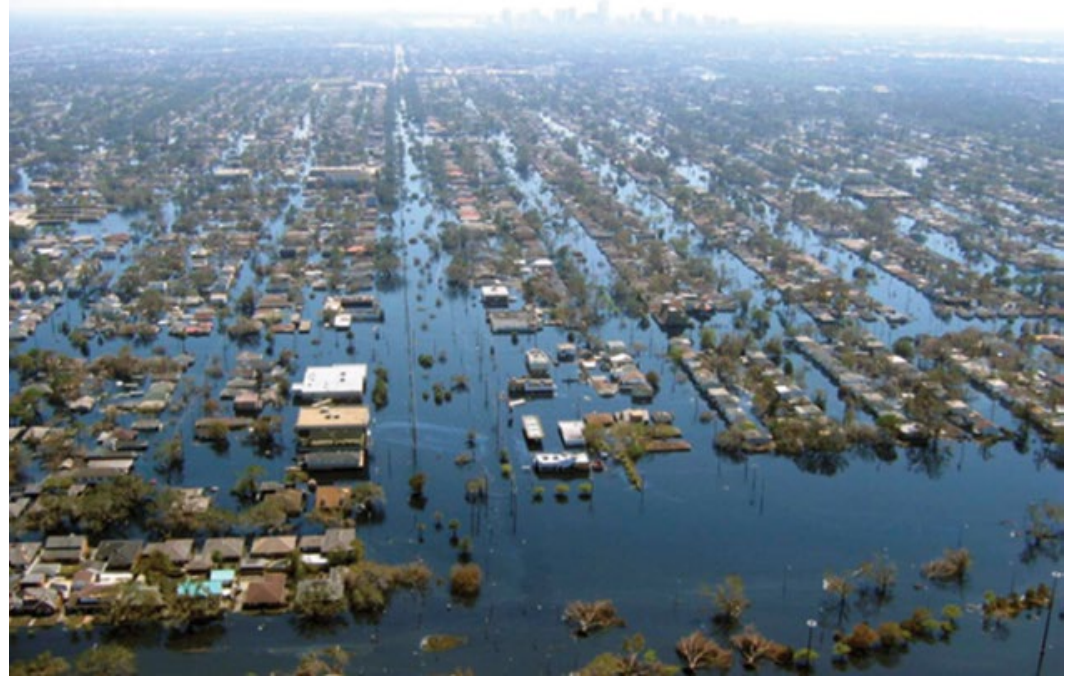

Figure 1: Aerial View of Post-Hurricane Katrina Devastation in a New Orleans Neighborhood.

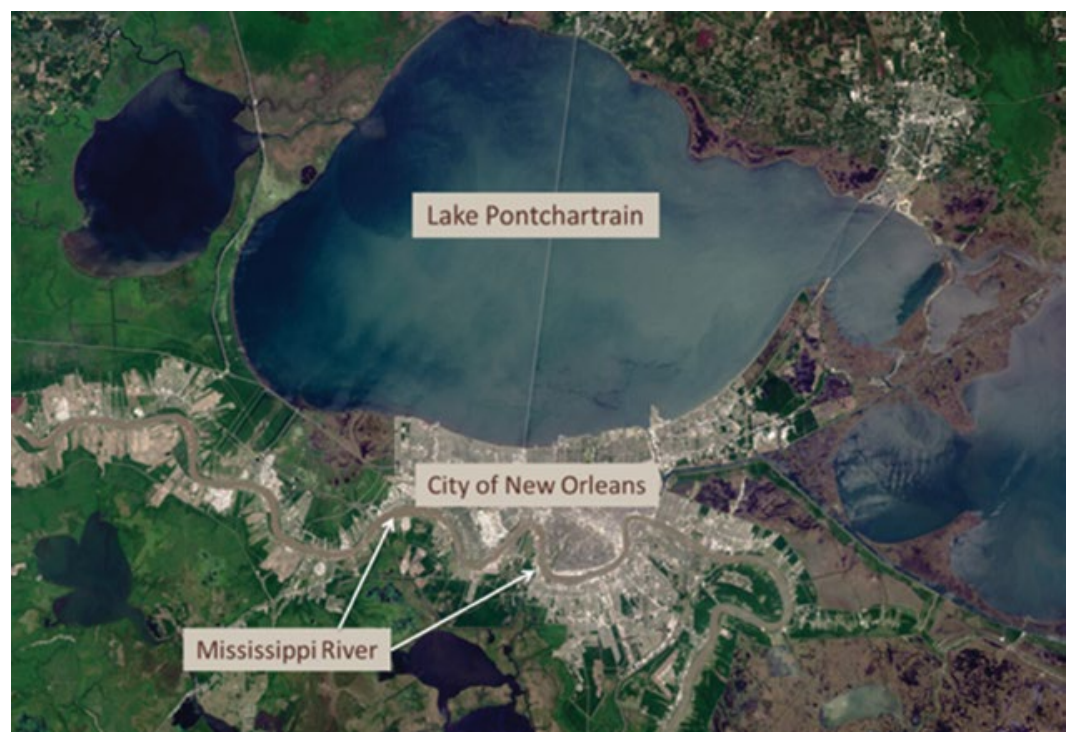

Figure 2: Aerial Map of New Orleans Geography.

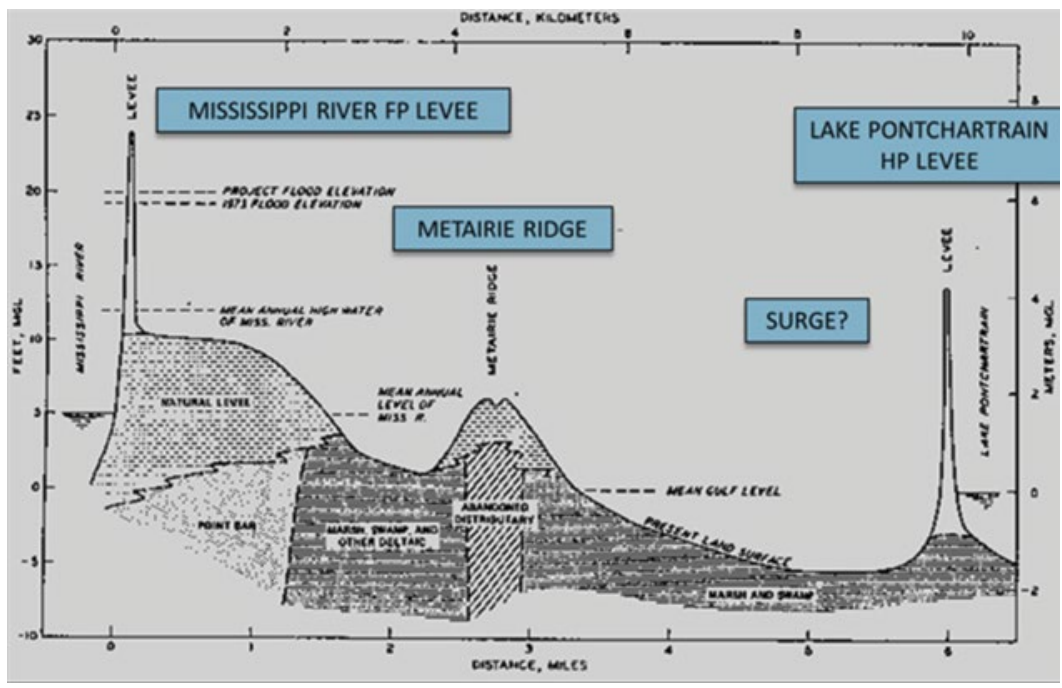

Figure 3: Cross-sectional Elevation of New Orleans. 


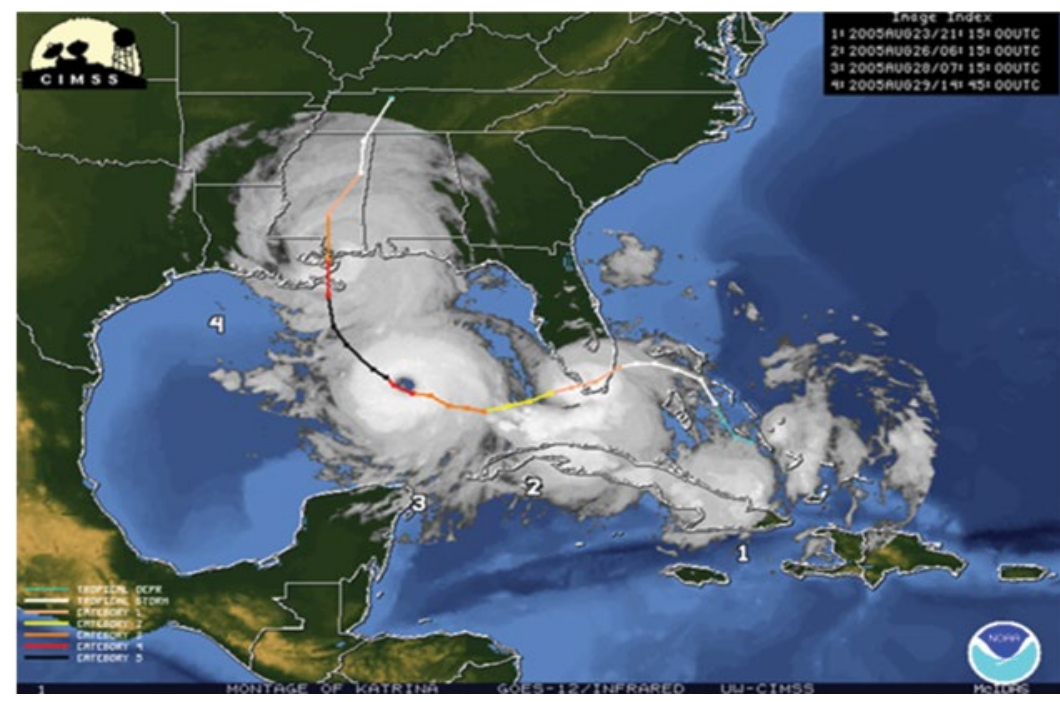

Figure 4: Hurricane Katrina's Path into the Gulf of Mexico.

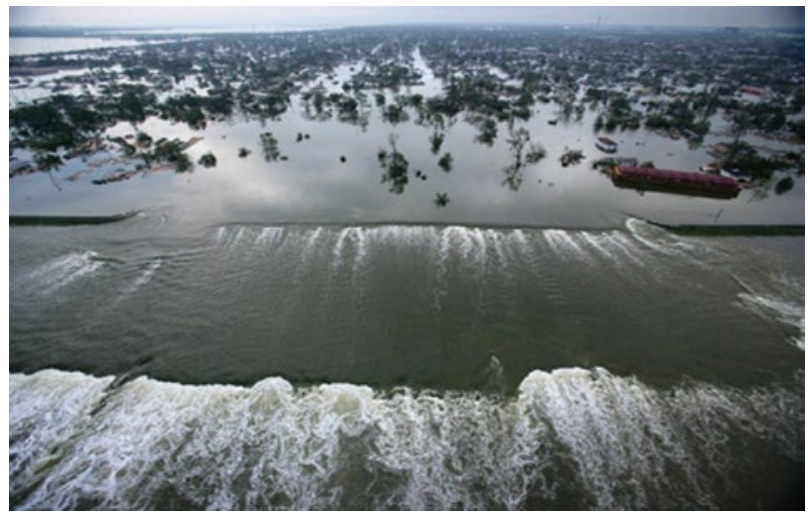

Figure 5: Hurricane Katrina Flood Wall Breach.

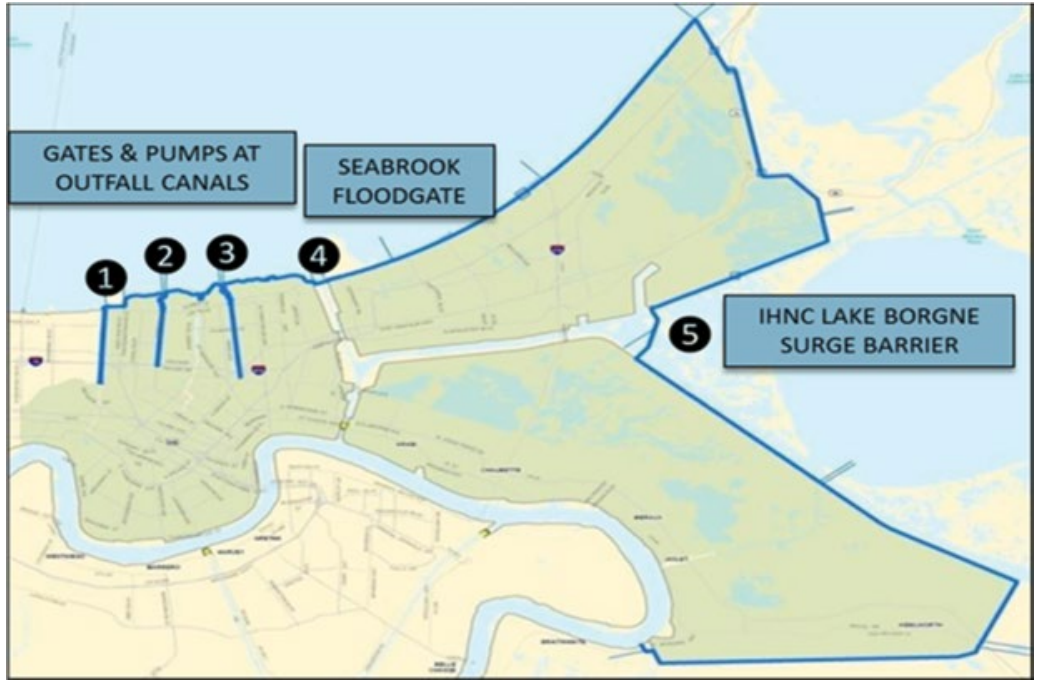

Figure 6: Blocking of the Five Major Storm Surge Avenues. 


\section{THE SOLUTION}

The $\$ 1.1$ billion USD IHNC Lake Borgne Surge Barrier consisting of a 10,000-foot-long, 26-foot high barrier wall, sector gate, barge gate, lift gate, and a complete floodwall closure of the Mississippi River Gulf Outlet (MRGO) became the solution to New Orleans' unique risk reduction requirement to block one of the five major storm surge avenues. To eliminate the need to raise 30 miles of levees and floodwalls, the surge barrier was placed at the convergence of the MRGO and the Gulf Intercostal Waterway (GIWW), therefore moving New Orleans' first line of defense 12 miles from the city center (Fig. 7). Because of this solution, the existing IHNC basin became the second line of defense and utilized as a retention basin to safely hold water to an elevation of +12 feet at the lowest point along the basin.

\section{KEY FEATURES}

The GIWW is an active navigation channel and requires unobstructed passage at all times. Because of this, the design of two separate 150-foot wide gate structures resulted. A bypass barge gate was constructed first and served as the marine traffic bypass channel during the construction of the sector gate monoliths across the main navigation channel.

The GIWW's 150-foot-wide bypass channel is controlled by a 5,714- ton concrete barge swing gate (Fig. 8). The gate can be closed, ballasted to a seated position, and locked

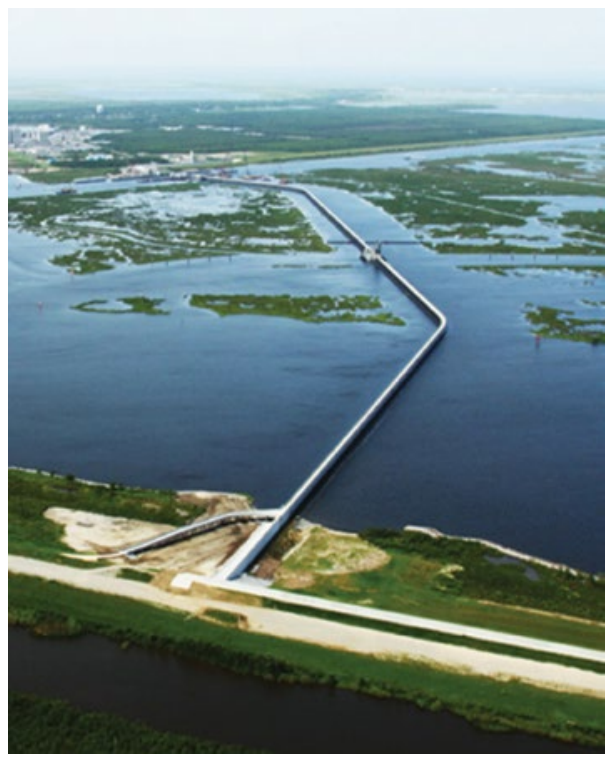

Figure 7: New Orleans' First Line of Defense: IHNC Lake Borgne Surge Barrier.

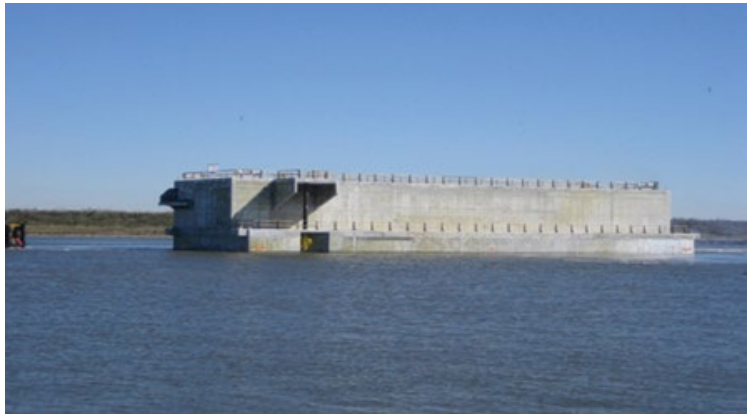

Figure 8: Concrete Barge.

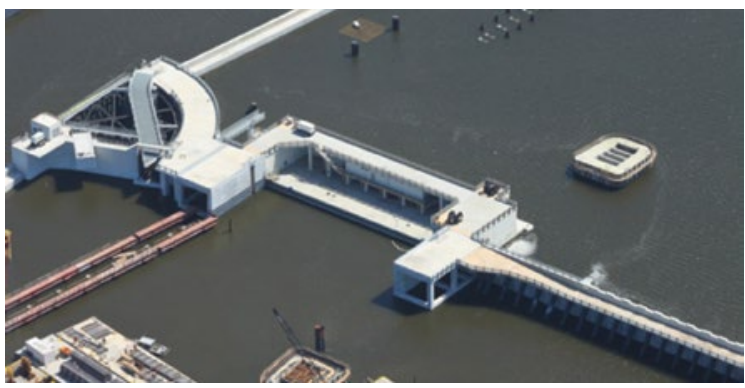

Figure 9: GIWW Bypass Barge Gate.

into place atop four closure pins in the event of a storm. Designed for not only significant loads that the structure might sustain during a 100-year storm, but also for impact loads from passing barges, as of 2012, thousands of barge tows have safely passed the barge swing gate (Fig. 9).

The 150 -foot wide main channel is controlled by a 675 tonper-leaf hydraulically operated buoyant steel sector gate (Fig. 10).The majority of the gate's weight is located at the extreme end of its 90 -foot radius where the heavy skin plate assembly is located, along with a bridge designed to support an HS-10 truck. By using buoyant tanks behind the skin plate, perimeter support was provided to relieve the load on the dinge at the monolith. These buoyant tanks are vital to the minimization of the gate's weight and were designed to allow for fabrication in a separate facility prior to insertion into the gate structure. The tanks have minimal maintenance concern and are ballasted to the control contact with the gate sill.

The third and final gate of the IHNC Lake Borgne Surge barrier is the 132-ton vertical lift gate at Bayou Bienvenue. Designed to pass commercial and recreational fishing vessels, this structure closes a 56-foot-wide opening where the barrier wall intersects the bayou, and when raised, provides 35 feet of clearance from water at an elevation of +1 foot (Fig. 11).

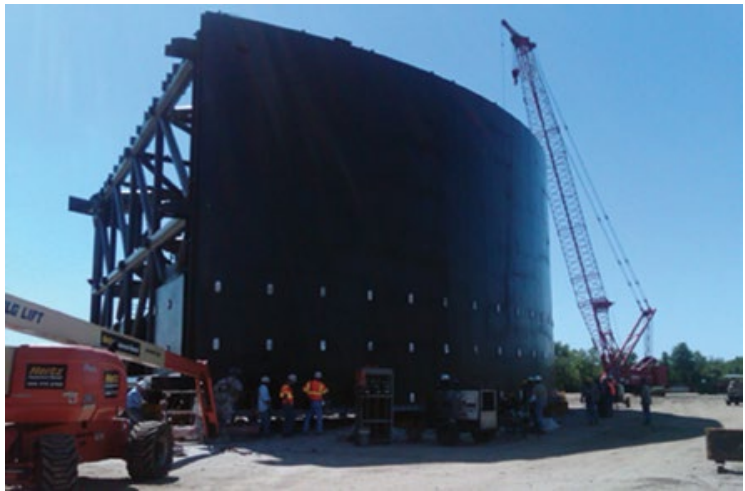

Figure 10: Sector Gate in Fabrication at Delcambre, LA.

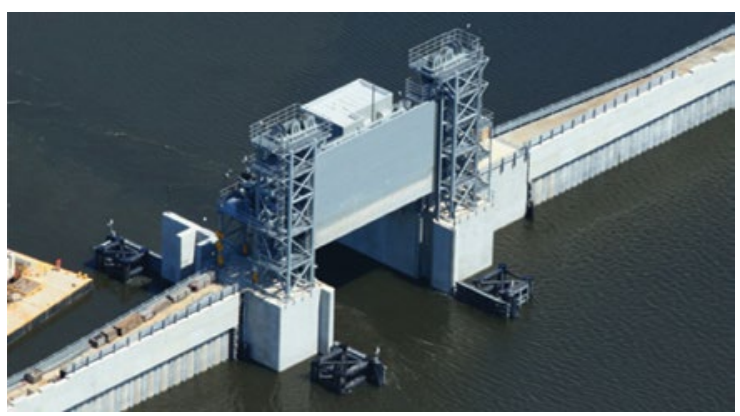

Figure 11: Bayou Bienvenue Vertical Lift Gate. 
The barrier wall itself is made up of 66-inch-diameter, 144-foot-long spun cast piles; 18-inch closure piles; 36-inch steel batter piles on the protected side; both precast and cast-in-place deck sections; and a parapet wall (Fig. 12). The crenellations of the wall minimized the wave overtopping volume in the IHNC retention basin while maximizing design efficiency by allowing the designers to use the lower crenel elevation as the top of the wall for design. This was particularly important because two of the five largest commercially available marine based cranes were used for pile driving of the barrier wall piles. Both the 66-inch-diameter and field spliced 250 -foot-long 36 -in pipe piles were approaching the handling and driving limits of the cranes. Much longer piles would have necessitated construction of custom pile driving equipment which would have increased costs and potentially put the June 1, 2011 goal of attainment of hurricane risk reduction at peril.

\section{RESILIENCY}

All three gates were designed with back-up generators and the ability to be closed manually should power not be available. The sector gate and barge gate can also be manually opened with tugs to allow water to drain from the IHNC basin. In addition, all structures were designed to withstand a 500 -year storm with no catastrophic damage.

\section{INNOVATION AND MODELING}

Taking advantage of the existing water storage capabilities, the Lake Borgne solution allows for storage of 226.5 million cubic feet of water from wall overtopping. Because there was no industry standard methodology precedent for calculating the magnitude of wave downfall forces, the project team was required to develop new methodologies and consult with pre-eminent experts from around the world. To determine whether certain theoretical loads would address wave impact, wave downfall, and plunging forces on the barrier wall and sector gate, testing on physical models became a key tactic in the planning and testing for the design of each feature. In addition to withstanding hurricane loads, the entire IHNC Lake Borgne Surge Barrier and gates are designed to resist seismic events.

Physical modeling was performed to confirm the effectiveness of the barrier's performance and consequently, the findings from this modeling extensively informed the design and construction of the barrier's features (Fig 13). A floodwall model was utilized to verify the over topping rate and to

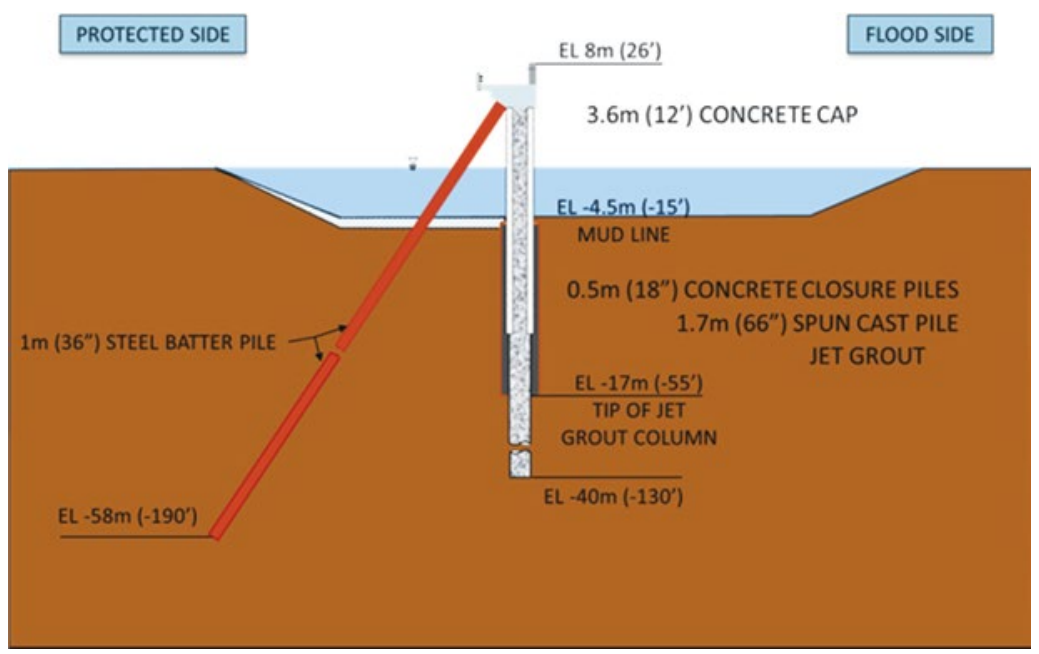

Figure 12: Cross-section Drawing of Floodwall.
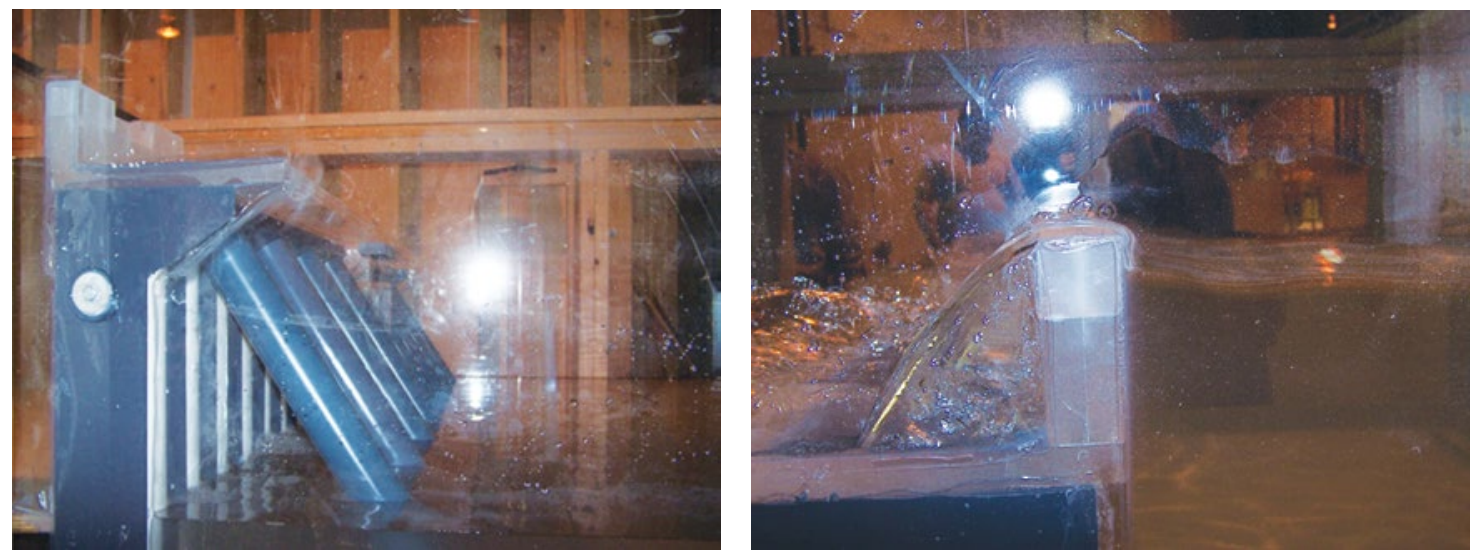

a)

b)

Figure 13: Barrier Wall Physical Model. 
demonstrate the effectiveness of the plunge pool/energy dissipation basin. This particular model demonstrated the effectiveness of the braced pile wall and the scour stone design.

A large basin model was created for the GIWW sector gate and surrounding area. The team used this model to study the effects of wave forces on the gate reflecting off land-based T-walls and approach walls. A simplified model determined gate forces from a reverse head location. Understanding forces generated on the gate while opened in a controlled manner were important for sizing much of the gates' structure and mechanical equipment. A second, detailed model wave basin model was developed to study the effect of the hurricane-induced waves. Both mass and stiffness were modeled to determine hydro-elastic effects such as gate vibration, wave slamming, and wave downfall (Fig. 14).

The results of the model trials determined that previously established USACE design curves for sector gates were not valid for the GIWW sector gates. The addition of buoyancy tanks, in lieu of wheels, altered the design curve substantially. Model results were used by the designers to select the actuating cylinder size and finalize monolith and gate attachments structure (Fig 15). During storm surge and wave testing, peak horizontal pressure distribution near convergence of gates was provided, which correlated well with design pressure. Uplift pressures on overhanging roadway were provided, confirming recommended design pressures were appropriate. Peak forces at pintle base, hinge, and locking cylinder, as well as frequency response analysis of structure due to impacting waves and overtopping events were also provided as results of tests. The reverse head testing provided the peak hydraulic force needed to be overcome by actuating cylinder. This result allowed optimization of the hydraulic system by designers. Reverse head testing also provided both the force curves as function of gate opening for different water levels, and key descriptions of hydraulic features such as zone of flow separation and eddy shedding associated with frequency response of the gate.

Major contributions to the design of the Sector Gate were a result of these extensive models and tests. A larger size hydraulic actuation cylinder was selected by the designers based on Reverse Head testing results. Pintle base casting design was finalized using the peak forces provided and appropriate safety factors. Horizontal wave pressures confirmed deterministic design values were appropriate, and uplift pressures were considered in final analysis of overhanging roadway. Ultimately, the use of advanced modeling provided important technical information and validated design assumptions.

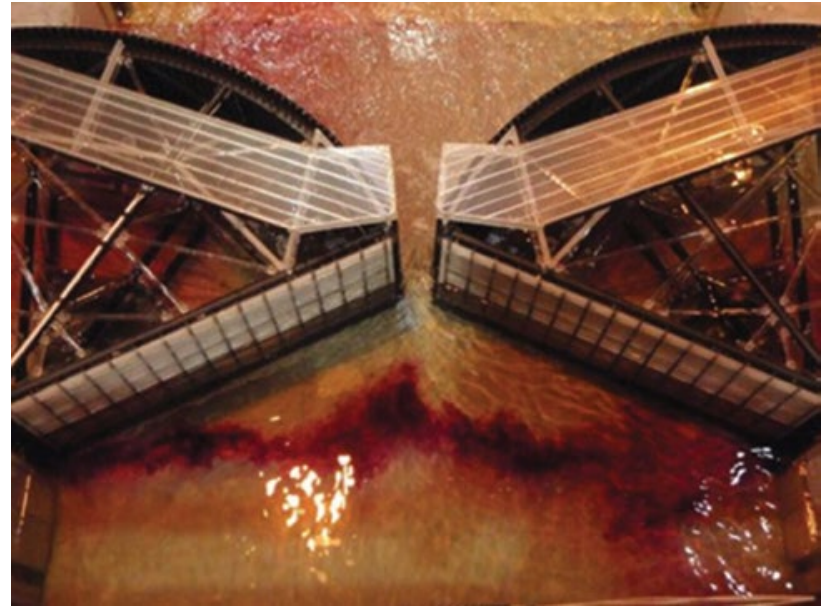

a)

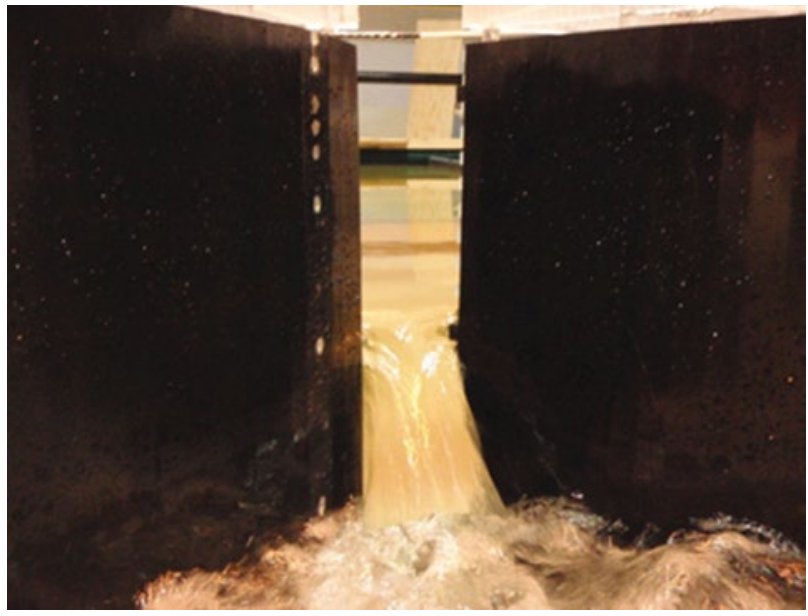

b)

Figure 14: Sector Gate Wave Basin Model: Operating Forces.

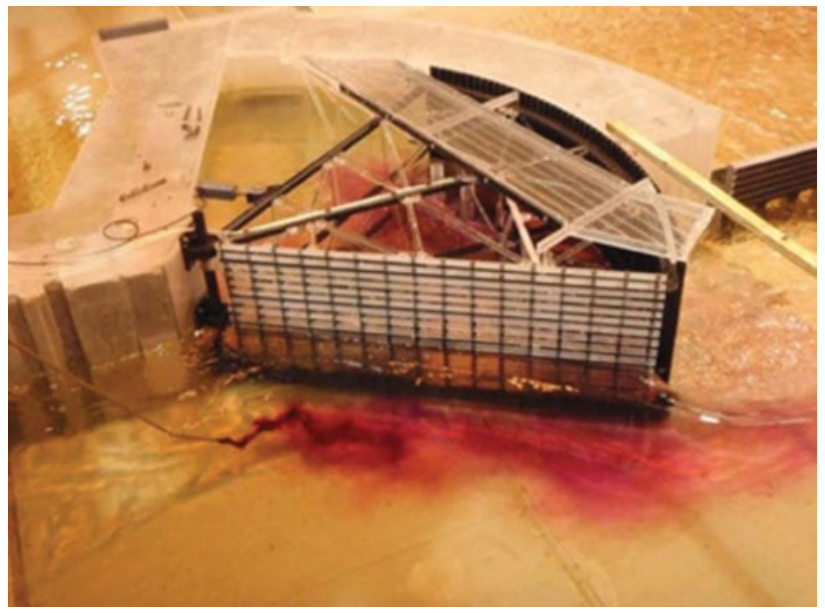

a)

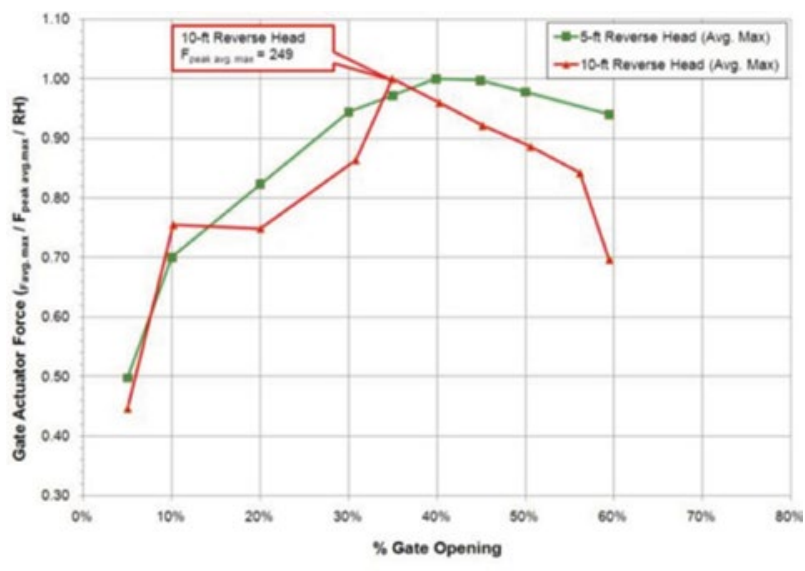

Figure 1 Non-dimensionalized Average Maximum Forces

Figure 15: Sector Gate Operating Force Model Results. 


\section{CONSTRUCTION AND COMPLETION}

The contract was awarded in April 2008, and construction began the following December. Using a temporary trestle construction, the first 66-inch-diameter pile was driven on May 9, 2009 and the final 66-inch-diameter pile on October 23, 2009 (Fig 16). Because of the rapid nature of the designbuild schedule, the project was completed in only four years instead of fifteen-plus years which is common for a project of this complexity. To maximize project efficiency and stay on schedule, decision regarding material procurement and fabrication were made prior to design completion. Quick decision-making was made possible by the close collaboration between the design team, USACE, and the State of Louisiana. Because of efforts by all, 100-year-level risk reduction was attained on May $24^{\text {th }} 2011$, surpassing the USACE's goal for completion by the 2011 hurricane season (Fig. 17).

The IHNC Lake Borgne Surge Barrier is an example of exemplary advance in science, planning, technology, and engineering. Complications caused by the accelerated schedule, procurement requirements, and the project site location posed serious challenges, but did not hinder the surge barrier's completion. Each feature in this colossal designbuild project created a system that confidently protects and restores vibrancy to New Orleans and its inhabitants today (Fig. 18).

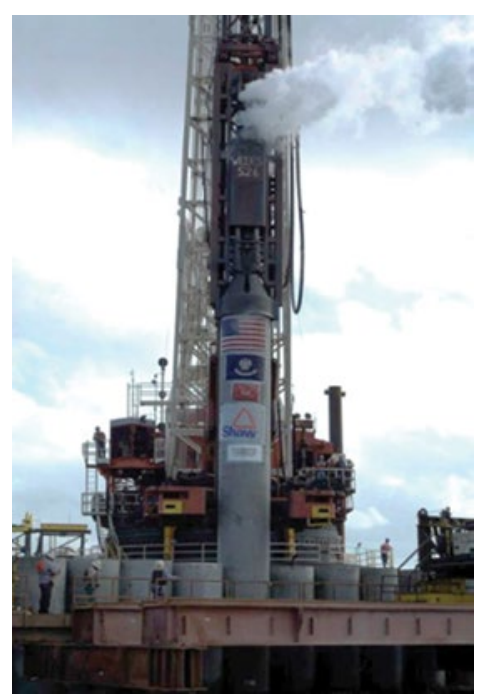

Figure 16: Final Pile Driven, October 23, 2009.

\section{ACKNOWLEGMENTS AND THANKS}

U. S. Army Corps of Engineers

Shaw E\&I

Ben C. Gerwick/COWI

AECOM/ENSR

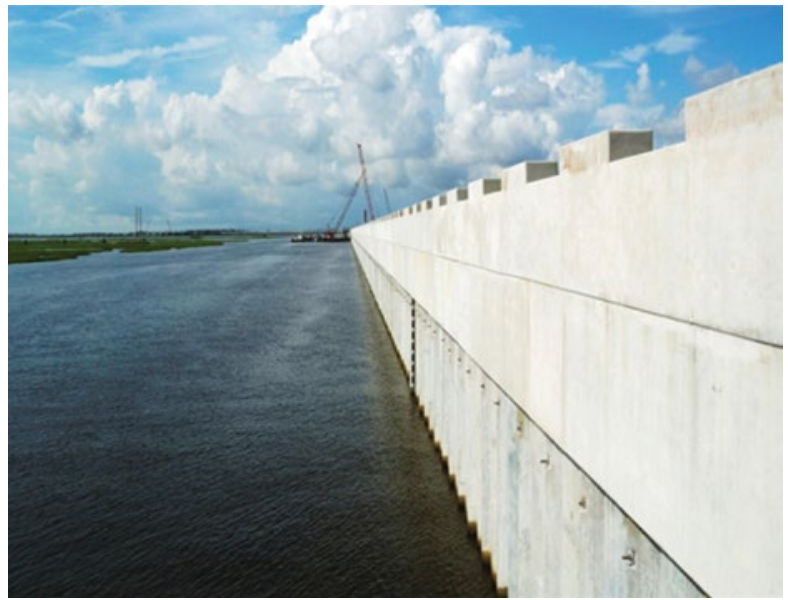

a)

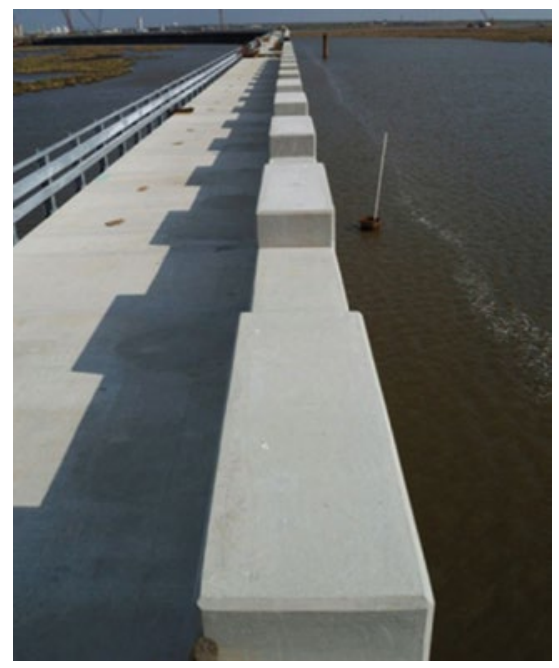

b)

Figure 17: Floodwall Parapet.

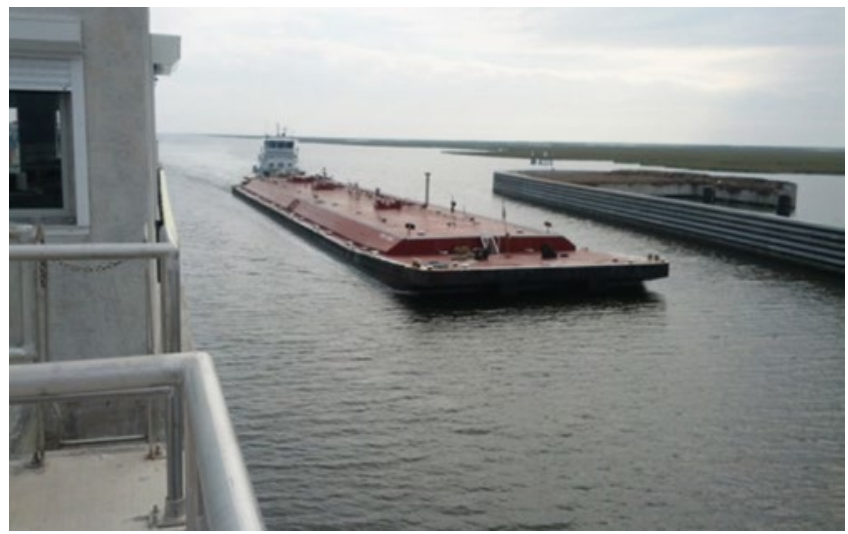

Figure 18: Safe Passage through IHNC Lake Borgne Surge Barrier. 